\title{
Utilization of Polypropylene (PP) Plastic Waste to Fuel Oil by the Pyrolysis
}

\author{
Nurmasyitah*, M. Jahari, H Saputra \\ Physics Education \\ Universitas Samudra \\ Aceh, Indonesia \\ *nurmasyitah@unsam.ac.id
}

\begin{abstract}
The increasing number of residents causes an increase in the volume of waste, especially plastic waste. Pyrolysis is the process of breaking down complex polymer structures to become simpler through a thermal (heating burning) process without using oxygen. Liquid smoke can also mean the result of cooling and melting smoke from biomass material that is burned in a closed tube. This study aims to determine the processing of unused Ploypropyline plastic waste into alternative fuels by pyrolysis process. The pyrolysis process was carried out at the reactor for 5 hours with 500 grams of waste producing $160 \mathrm{~mL}$. The results showed that the density of pyrolysis oil was 0,812 $\mathrm{g} / \mathrm{ml}$. The time needed to burn out an object is 5,28 minutes. Heating water using pyrolysis oil produces a temperature of $780 \mathrm{C}$ at 5 minutes heating time with a volume of water lost (evaporating) of $4,8 \mathrm{ml}$. Of the four parameters that have been observed, the quality of pyrolysis oil is between premium oil and kerosene.
\end{abstract}

\section{Keywords—plastic, pyrolysis, liquid smoke}

\section{INTRODUCTION}

Since 1970 the first time the discovery of plastics to date of us plastics and plastic goods increasingly increased. Increased use of plastics is a consequence of developing technology, industry, and population in Indonesia. The need for plastic in Indonesia continues increases until it has increased on average 200 tons per year, and in 2002 had recorded 1.9 million tonnes, 2003 increased to 2.1 million tons, and 2004 continues to increase to 2.3 million tons per year. In 2010 plastic use was recorded at 2.4 million tonnes and on in 2011 increased to 2.6 tonnes, as a result of increasing use of plastic is increasing also plastic waste [1].

It is a shame until now a very large amount of plastic waste only thrown into the landfill or burned without being used as much as possible, so that the garbage will be a source of disease and calamity, such as water pollution, environment, air to the occurrence of landslides due to the pile of garbage mountains. Plastic that basically has many excess causes demand plastic use continues to increase. On generally plastic raw materials have advantages such as lighter, insulators, and processes cheaper manufacture. Behind the advantages also has an after impact the item does not again used [2].

Processing of plastic waste into problem because plastic is a material cannot decompose naturally (non-biodegradable) thus processing plastic waste no landfill or open dumping done. In processing plastic waste Much is done by burning, however burning waste can have a negative impact to the environment in the form of pollution air. Other plastic waste processing with recycle plastic waste into shapes others, but this recycling is just changing plastic into a new form is not it take down the volume of plastic waste, so that when plastic recycled products are already lost function it will return to waste Plastic. So, another alternative is needed handle the volume of plastic waste [3].

When viewed from the process of making plastics come from petroleum residue then of course plastic waste can be used back, then the potential for plastic waste processed into alternative fuels. Pyrolysis plastic waste is a form of process recycling by turning plastics into fuel. Besides being useful for reducing amount of plastic waste, plastic waste pyrolysis also useful for providing fuel with a high enough energy value. This matter proven by the results of the research conducted by Jatmiko Wahyudi, which shows that quality pyrolysis oil under kerosene however above diesel oil. Research conducted by Gina Lova Sari, which indicates that the pyrolysis is waste plastic can produce up to $81 \%$ oil which fall into the category of paraffin, iso parafin, olefins, naphthene and aromatics so it deserves used as fuel. And research which was done by Judhid Adi Mursino, which is indicates that the amount of pyrolyzed oil is produced, namely $74 \mathrm{~g}$ at $400 \mathrm{oC}$ pyrolysis temperature with the calorific value obtained from oil the distillation was $1,572 \mathrm{~J} / \mathrm{gr}$.

From the results of research that has been carried out by several researchers above, the pyrolysis process can be used as the utilization of plastic waste into fuel oil. So, it needs to be redeveloped using a different type of plastic. Then the researchers conducted research with the title "Utilization of Polypropyline (PP) Plastic Waste to Fuel Oil by the Pyrolysis Process". The purpose of this study is to know waste 
processing plastic Ploypropyline becomes unused alternative fuel by pyrolysis process.

\section{THEORETICAL BASIS}

Plastic is one of the most frequently used materials, in everyday life we cannot escape the use of plastic. Plastic is the material most widely used to make various household items in the form of plates, jars, grocery bags and buckets. Plastic is also the most common material used to package various products on the market, from food to cosmetics. However, of its various uses, plastic can also have a negative impact on the environment because of its difficult to decompose, so that it will become waste and pollutants for our nature for a long time. Plastics can also have a bad impact on health if not used properly, so we need to be more careful in recognizing the types and characteristics of plastics around us.

Cording Hartulistiyoso [3], Berdas a Refresh kinds of plastic products, there are 6 types of plastics are Polyprothylene Terephthalate (PET), High Density Polyethylene (HDPE), polyvinyl chloride (PVC), Low Density Polyethylene (LDPE), Polypropylene (PP), Polystyrene (PS) and Other.

More than $70 \%$ of plastic waste that is currently produced is Polyethylene (PE), Polypropylene (PP), Polystyrene (PS), and Polyvinyl Chloride (PVC), so that the larger the studies being carried out are related to these four types of polymers (see in Table 1)

TABLE I. CHARACTERISTICS OF Plastic TYPES

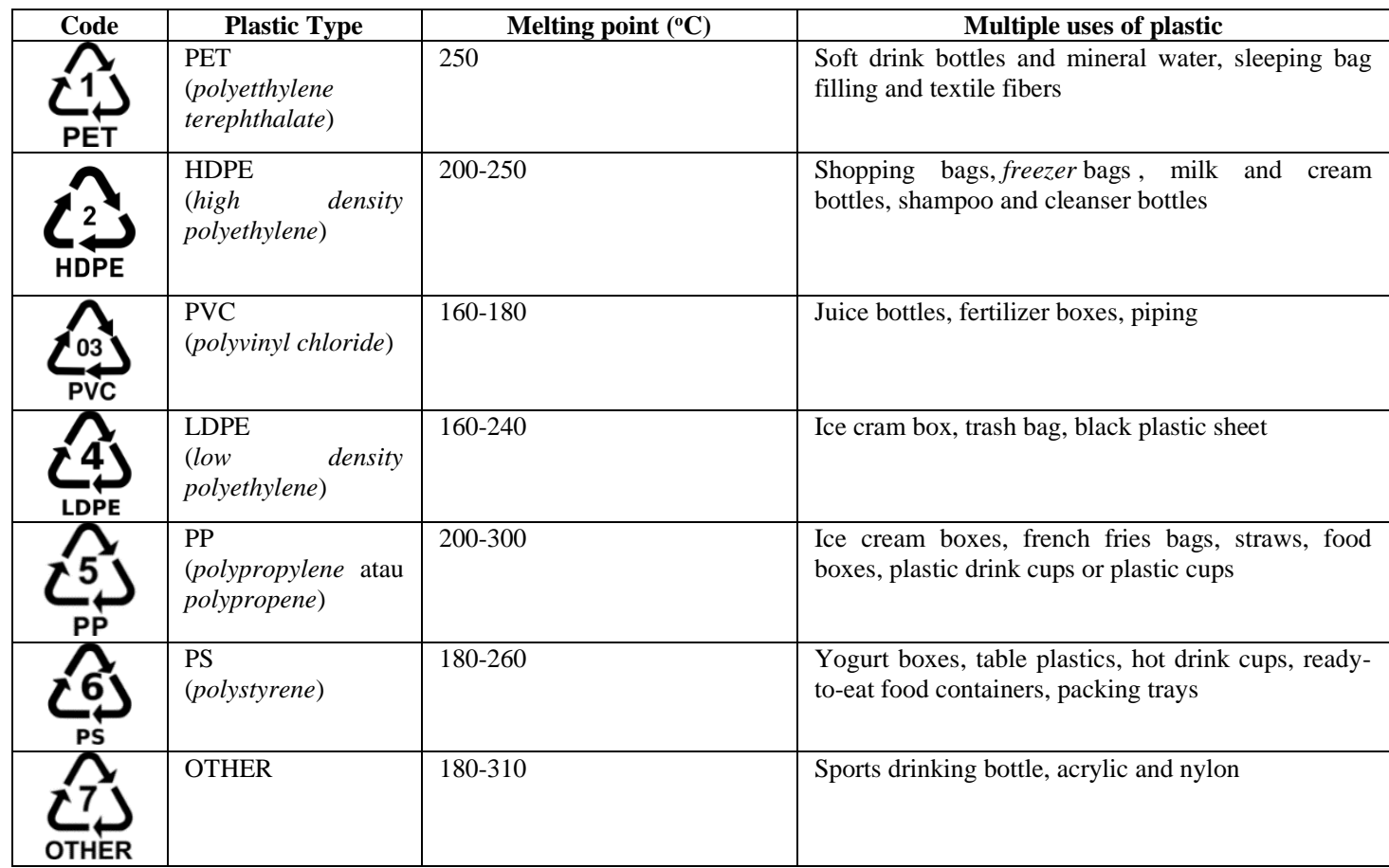

Plastic waste can be divided into household plastic waste and industrial plastic waste. Household plastic waste is produced related to everyday human activities such as food plastics, plastic packaging, and beverage plastic. Industrial plastic waste comes from the plastic manufacturing industry or industries engaged in processing. Based on its properties, plastics can also be grouped into two types, namely thermoplastic and thermosetting. Thermoplastic is a certain plastic material that can be recycled and made into other forms of material through a heating process. Examples of thermoplastic include Polyethylene, Polypropylene, Nylon, Polycarbonate. Thermosetting is a plastic that cannot be melted down for recycling or other products. Examples of plastics that include thermosetting include Phenol formaldehyde, Urea Form aldehyde, Melamine Formaldehyde.
Methods that can be used to convert plastic waste into liquid fuel include: pyrolysis, thermal cracking, and catalytic cracking. Of the three methods, the pyrolysis method is a very promising method. Pyrolysis comes from two words, namely, pyro which means heat and lysis which means decomposition or degradation, so that pyrolysis is the decomposition of biomass by heat at temperatures of more than $150{ }^{\circ} \mathrm{C}[3]$.

The pyrolysis method can be used to process household waste, such as paper waste, plastic waste, and textile waste. The liquid produced from the pyrolysis process is a mixture of complex organic compounds including styrene, ethylbenzene, toluene, and others. Process pirolisis produce solids containing char or residues and organic matter which 
pitch bladder in raw materials. In addition, pyrolysis also produces gas consisting of hydrocarbons, $\mathrm{CO}$ and $\mathrm{CO}_{2}$ which have high heating values [5]. The pyrolysis process also involves various reaction processes including decomposition, oxidation, polymerization and condensation [6].

Pyrolysis is the process of breaking down complex polymer structures into simpler ones without using $\mathrm{O}_{2}$. The conversion process of plastic waste starts from the drying process so that clean and dry plastic is obtained. The condition of the plastic can affect the quality of the product produced, then the next process is by heating the reactor at $350-900{ }^{\circ} \mathrm{C}$. The heat generated from this temperature causes the plastic polymers inside to soften. The gas formed contains various elements and compounds which are then separated through a condensation process to produce oil and gas [4]. Rodiansono, et al [4] state that pyrolysis is capable of producing oil and gas, which amounts to $70-80 \%$ and $5-10 \%$, respectively.

Based on an analysis conducted by the Oil and Gas Agency (Lemigas), the oil produced from used plastics has unsaturated properties and the ratio between carbon and hydrogen is unbalanced so that there are links in the chain that are not filled. The oil is brownish yellow in color, but it can burn a stove or torch. This porolytic oil is flammable, emits soot, and has a stimulating smell and this pyrolysis oil can be recovered so that it has saturated and stable properties [1].

Research conducted by Jatmiko Wahyudi, Hermain Teguh Prayitno and Arieyanti Dwi Astuti [3], explained that the density of pyrolysis oil is $0.8 \mathrm{~g} / \mathrm{ml}$, the time interval required to burn an object is 4.02 minutes. Heating water using pyrolysis oil produces a temperature of $75^{\circ} \mathrm{C}$ at 4 minutes of cooking time with a volume of water that is lost (evaporates) of $12.6 \mathrm{ml}$ and a density of kerosene $0.78 \mathrm{~g} / \mathrm{ml}$, the time interval required to burn off an object is 3.39 minutes [7]. Heating water using kerosene produces a temperature of $80^{\circ} \mathrm{C}$ in 4 minutes with the volume of water lost (evaporates) of 8.4 ml. For gasoline (premium), research by Gusmil Diana Br. Sitepu, Saipul Bahri Daulay and Adian Rindang [8], explain that the density of gasoline (premium) fuel is 0.71 $0.77 \mathrm{~g} / \mathrm{ml}$.

Research conducted by Imtiaz Ahmad [9], conducted a research on pyrolysis of polypropylene and polyethylene to premium oil products, after comparing yield type hydrocarbons, PP gave high yields of paraffin hydrocarbons while HDPE provided olefins and naphthene, all liquid fractions were also analyzed for properties. fuel and the results showed that the two liquid fractions of the fuel met the fuel class criteria.

Research conducted by Ferdianta Sembiring [9], conducted research on the pyrolysis catalyst of mixing plastic waste, in this study the plastic waste used was PP and PET. The best temperature for producing the highest quality liquid oil without a catalyst is the highest temperature of $500^{\circ} \mathrm{C}$, when using a catalyst is the opposite. By using a catalyst, the number of compounds has increased the calorific value of the oil. PET is a type of plastic that is not suitable to be treated by pyrolysis, but by mixing PET with PP as a raw material and using the right catalyst problems can be minimized.

Factors that can affect the quality and quantity of the oil produced are temperature and time, the type of plastic and the use of various types of catalysts. The higher the temperature and the longer the pyrolysis process, the greater the amount of oil produced, the type of plastic used also determines the quality of the oil produced and the use of catalysts in the pyrolysis process is able to accelerate the conversion which produces better quality oil, and the catalyst is able to increase the fracture. ter finished in the pyrolysis process [4].

The general definition of liquid smoke (liquid smoke) is a result of distillation or condensation of steam from indirect or direct combustion of materials that contain a lot of carbon and other compounds. The raw materials that are widely used to make liquid smoke are coconut shells, wood, palm oil, pulp from saws, and other biomass. Liquid smoke can also mean the result of cooling and liquefaction of the smoke from the biomass material which is burned in a closed tube. Smoke, which was originally solid particles cooled and then turned into liquid, is called liquid smoke [10].

According to Demaji [11], Liquid smoke is a dissolved dispersion of smoke in water, which forms condensation or condensation from steam resulting from pyrolysis of materials which contain lots of lignin, cellulose, hemicellulose and other carbon compounds.

Liquid smoke has various functional properties, including:

- Provides aroma, taste, and color due to the presence of phenol and carbonyl compounds;

- As a natural preservative because it contains phenol and acid compounds which act as antibacterial and antioxidant.

Liquid smoke can also reduce lead smoke levels in soybean seeds and organic insecticides [11].

The nature of liquid smoke is influenced by the main components, namely cellulose, hemicellulose and lignin, whose proportions vary depending on the type of material to be pyrolyzed [12]. Liquid smoke also contains harmful compounds, namely tar and benzopiren compounds which are toxic and carcinogenic and cause damage to essential amino acids from proteins and vitamins. This effect is due to the presence of a number of chemical compounds in the liquid smoke that can react with food components. Efforts made to separate the hazardous components in liquid smoke can be carried out by means of redistillation, namely the process of separating a solution based on its boiling point [12].

\section{RESEARCH METHODS}

Waste utilization research polypropyline plastic (PP) as fuel oil by pyrolysis process carried out in Ocean University environment. Research held in December 2019. 
As for the tools and materials used in waste utilization research polypropyline plastic (PP) as fuel oil with the pyrolysis process includes a drill, scissors, measuring cup, stopwatch, thermometer, scales, iron glue, iron paralon, hoses, rings gas hoses, aqua bottles, buckets, used cans, water, polypropylene (PP) plastic waste, oil land, premium oil, wood, milk cans, and torch container.

Plastic waste used as the raw material in this research is plastic polypropylene (PP) in the form of a plastic cup used as bottled drinking water, cup These plastics are obtained from wholesaler's junk. Kerosene and premium oil used as a reference fuel the comparators are obtained from the Petrol Station General (SPBU) Pertamina so that the specifications fuel obtained according to the standard Pertamina, and water are used as coolants.

As for tool design and manufacture polypropyline (PP) plastic waste to be fuel oil by pyrolysis process (figure 1).

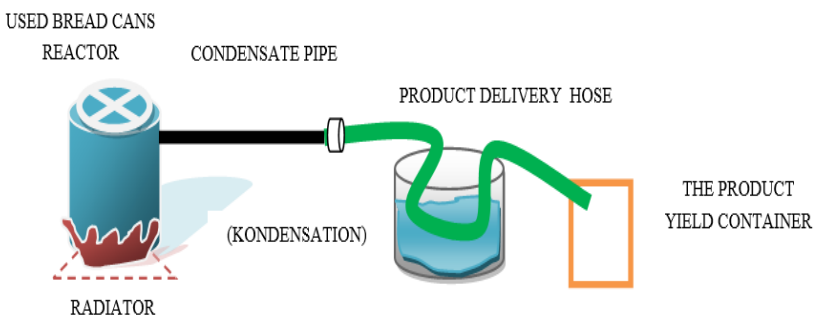

Fig. 1. A series of pyrolysis apparatus.

\section{A. Research steps}



Fig. 2. The step of experimental.

The plastic cup that is collected must be in dry and clean conditions as much as 500 gram is put into the pyrolysis apparatus equipped with a cooler and a container for the results pyrolysis. The plastic cup (PP) in the solid phase is modified into the liquid (oil) phase by using pyrolysis process.
According to Thorat [3], selection of PP type plastics is fuel oil produced from pyrolysis $\mathrm{PP}$ has better quality compared to PVC or PET (figure 2).

PP plastic is a type of plastic widely used in everyday life because it has good mechanical properties with low density, heat and moisture resistance as well as good dimensional stability. PP plastic also has an arrangement of hydrocarbon molecules the simplest by type other plastics. Phase change process from solid to liquid takes place in two stages, the first phase change from solid to gas is carried out by heating the plastic with using an LPG stove. The second, phase changes from gas to liquid in a way condensation (cooling) of gases formed on the first stage to obtain oil (liquid) [3].

\section{B. Analysis}

Density analysis of pyrolysis oil, kerosene and premium oil done by measuring volume and mass on each sample. Each sample was taken $160 \mathrm{ml}$ using a measuring cup, then the sample is weighed to obtain mass. The density of the sample is calculated using tenses:

$$
\rho=\frac{m}{V}
$$

Information, $\rho=$ Density $\left(\mathrm{kg} / \mathrm{m}^{3}\right)$

$$
\begin{aligned}
& \mathrm{m}=\text { Mass in the sample }(\mathrm{kg}) \\
& \mathrm{V}=\text { Sample volume }\left(\mathrm{m}^{3}\right)
\end{aligned}
$$

Analysis for pyrolysis oil yield, kerosene and premium oil done by analyzing the burning time of each fuel sample, in increasing temperature or heat water and measure the volume remaining water after heating with using each of the fuel samples.

Analysis of combustion time performance analysis done by taking $10 \mathrm{ml}$ each the fuel sample is fed into the furnace different. The time it takes for each fuel sample to burn the material until it runs out will be calculated and analyzed, the material used is $3 \times 1 \mathrm{~cm}$ wood.

Fuel sample performance analysis to heat water is done with using each sample as fuel to heat $10 \mathrm{ml}$ of water. Process done for 5 minutes and so on measure the temperature of the water that is heated with 3 different and measured fuel samples and analyzed.

Fuel sample performance analysis in evaporating water is done by measuring and heating $10 \mathrm{ml}$ of water for 5 minutes. Furthermore, the volume of water remaining after heating with 3 samples of material different types of burns are measured and analyzed.

The stages carried out on this research as shown in flow chart in the figure 3 below: 


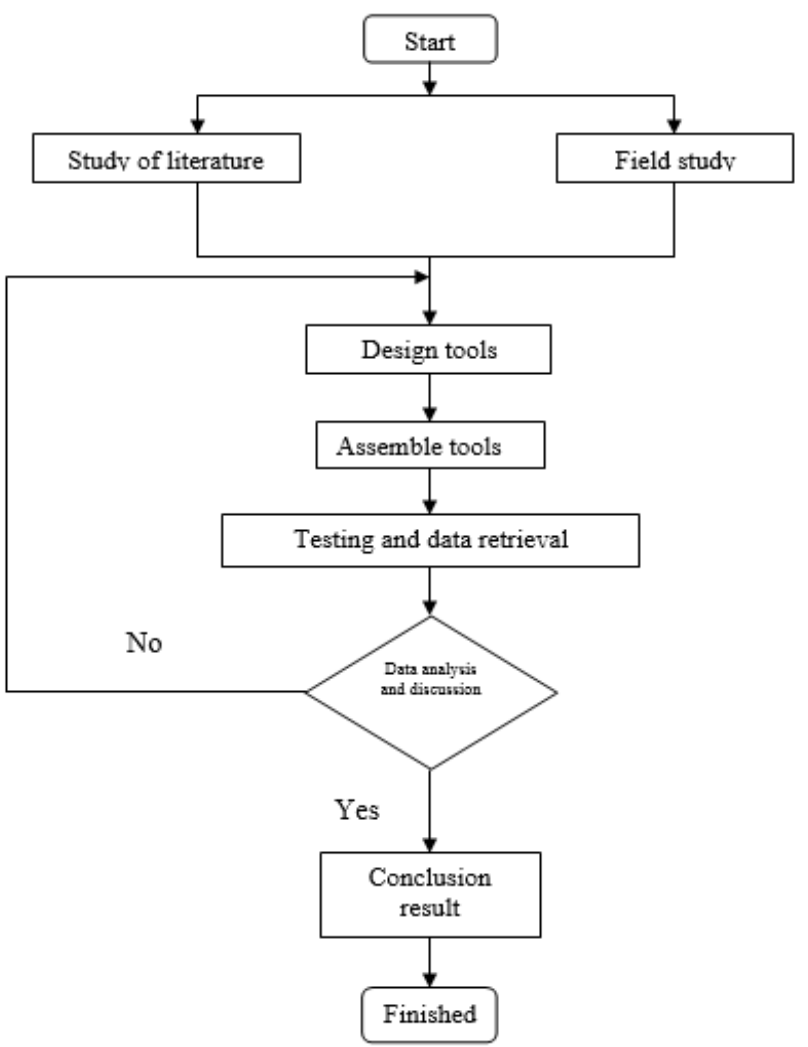

Fig. 3. Research flow diagram.

\section{RESULTS AND DISCUSSION}

Research results obtained from utilization of polypropyline plastic waste (PP) 500 grams to produce pyrolysis oil as much as $160 \mathrm{ml}$ with a long burning time 5 hours as follows figure 4,5 and 6 :



(a)

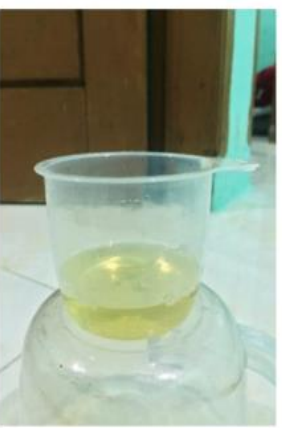

(b)

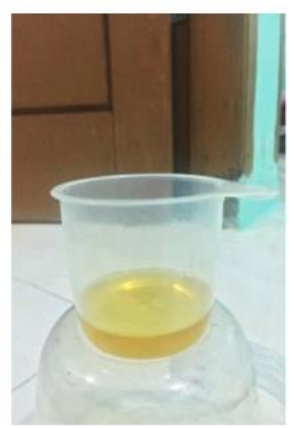

(c)
Fig. 4. (a) Pyrolysis, (b) Kerosene, and (c) Premium oil.


Fig. 5. Time long burning.


Fig. 6. Process of analysis of water temperature and volume lost.

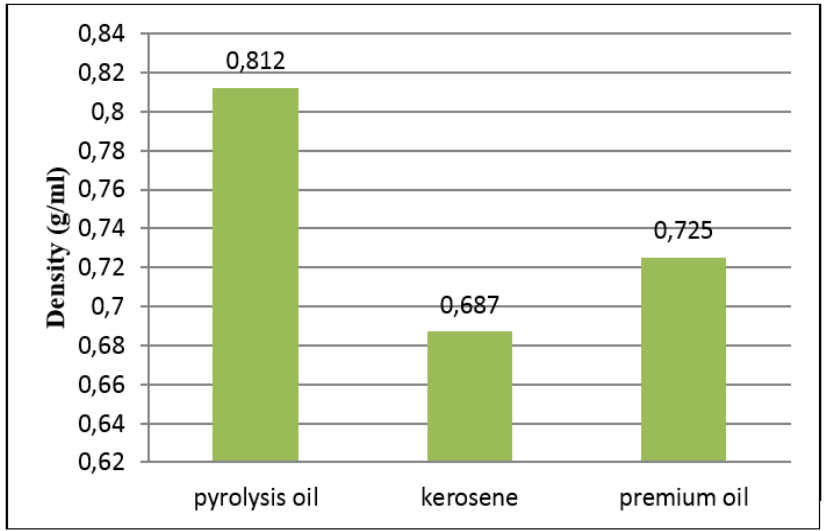

Fig. 7. Density.

Based on the calculation of density plastic pyrolysis oil, kerosene and oil premium shows that plastic pyrolysis results type PP of $0.812 \mathrm{~g} / \mathrm{ml}$ higher than the mass kerosene and premium oil that has density $0.687 \mathrm{~g} / \mathrm{ml}$ and $0.725 \mathrm{~g} / \mathrm{ml}$ (figure 7).

The higher the density of an object, the greater the mass of each volume. Pyrolysis oil has a greater density compared to kerosene and oil premium. 


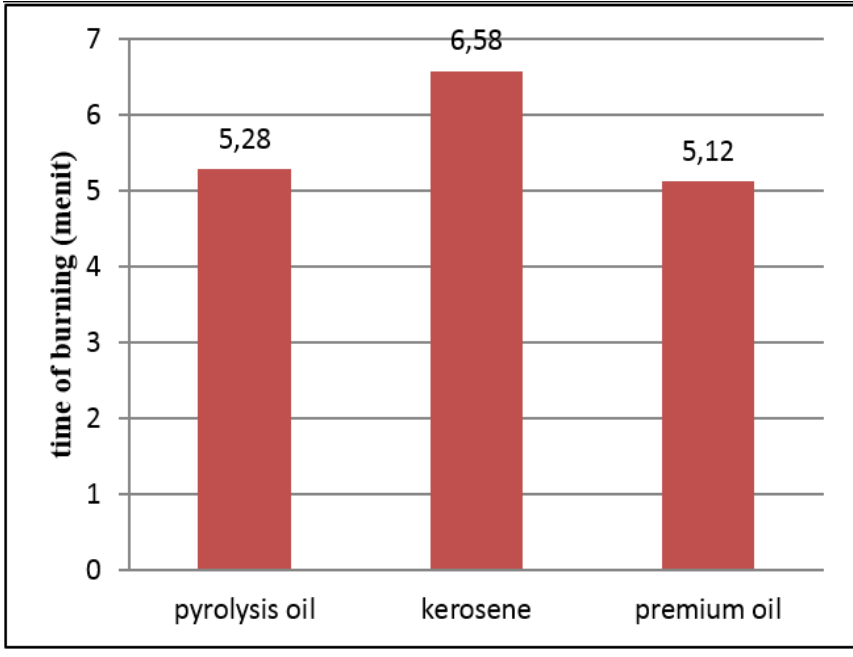

Fig. 8. Time of burning.

Based on Figure 8 it is known that kerosene produces burning time 6.58 minutes longest compared to 5.12 minutes premium oil and pyrolysis oil 5.28 minutes. This is due to the oil's flash point soil has the highest flash point between the two oils is $47.8^{\circ} \mathrm{C}$, meanwhile premium oil flash point is $-15^{\circ} \mathrm{C}$ to $43^{\circ} \mathrm{C}[3]$.

Flash point is connected directly with ease or not of a material burns can burn, resulting in a flash point the lower will cause the substance the easier it is burned, so that this physical property very important as a condition of a substance is said to be fuel. Even though it is deep This study did not calculate the oil flash point pyrolysis, Figure 8 can imply that Pyrolyzed oil has a larger flash point than kerosene but less than oil premium.

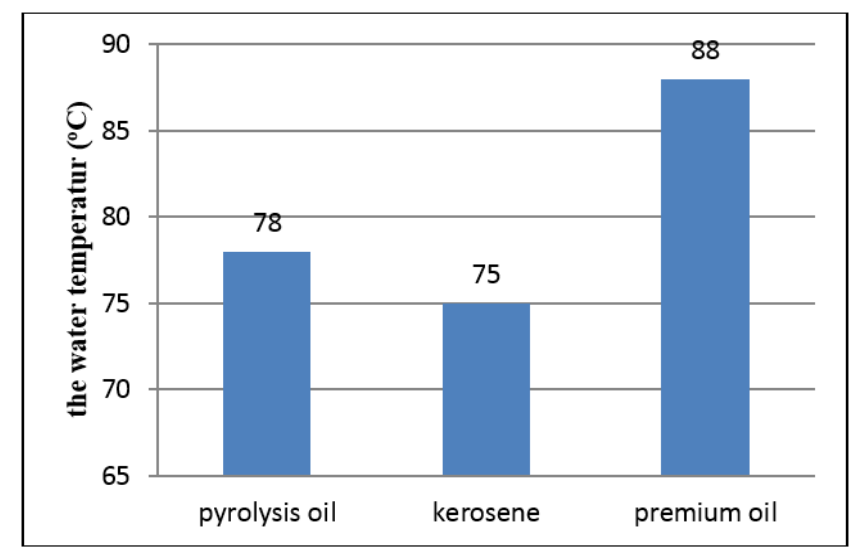

Fig. 9. The lost of water volume.

In this research, pyrolysis oil plastics are tested using a part of fuel to boil water within 5 minutes, so you can find out the amount water temperature. Water temperature resulting from cooking using pyrolysis oil will compared to kerosene and oil premium. The results of the water temperature are presented at Figure 9, from the results of the study it appears inversely proportional relationship, which is where the longer it burns, the water temperature the resulting will be lower. Measurement at this temperature is carried out at the same time the same for each type of oil. When water cup burned with oil premium is hot, then the water cup burned using pyrolysis oil starts to heat but the saucer of water is burned using kerosene is not hot yet.

Kerosene takes a long time long burning between the other two oils, so that the water is cooked using oil pyrolysis has the lowest temperature of $75^{\circ} \mathrm{C}$. Meanwhile, the water is cooked using ingredients pyrolysis oil has a temperature of $78^{\circ} \mathrm{C}$. This temperature is between kerosene and premium oil, because pyrolysis oil has the flash point which is also between kerosene and premium oil. So is oil premium that produces temperature in water the highest is $88^{\circ} \mathrm{C}$, because it has a point lowest flame $\left(-15^{\circ} \mathrm{C}\right.$ to $\left.-43^{\circ} \mathrm{C}\right)$. Point flame cannot be compared because limitations of the tester.



Fig. 10. The lost of water volume.

The large volume of water lost as a result heating done by using each fuel sample has been presented in Figure 10. Besides measuring temperature on boiling water, also testing ability Pyrolysis oil is done by measuring the amount of water volume lost (evaporated) at the process of heating water using oil the. The volume of water that evaporates is highest resulting from boiling water using premium oil $(5.6 \mathrm{ml})$, followed by oil pyrolysis $(4.8 \mathrm{ml})$ and the lowest was soil oil $(4.5 \mathrm{ml})$. The volume of water that evaporates this has a relationship directly proportional to water temperature. This is related to the flash point oil, the higher the flash point, the more long flame from the oil fire. This matter according to Figure 8 which illustrates that kerosene has a burning time the longest, followed by pyrolysis oil and oil premium.

\section{CONCLUSION}

Based on the results of waste Sampah Plastik polypropyline (PP) into fuel by a process pyrolysis can be concluded that:

- The pyrolysis oil from PP plastic waste produces 160 $\mathrm{mL}$ of 500 grams of polypropylene (PP) plastic waste about 5 hours of burning time. 
- The density of pyrolysis oil is $0,812 \mathrm{~g} / \mathrm{mL}$. means while, the time to takes a completely burn an object is 5.28 minutes.

- The flash poin of pyrolysis oil is between kerosene and premium oil.

- Burning the water using fuil phyrolisis oil produces a temperature of $78^{\circ} \mathrm{C}$.

- The burning at 5 minutes by the lost of volume water (evaporated) of $4,8 \mathrm{~mL}$.

\section{REFERENCES}

[1] D. Iswadi, F. Nurisa, and E. Liastuti, "Pemanfaatan Sampah Plastik LDPE Dan PET Menjadi Bahan Bakar Minyak Dengan Proses Pirolisis," J. Ilm. Tek. Kim. UNPAM, vol. 1, no. 2, pp. 1-9, 2017.

[2] J.A. Mursito, I.G.K. Sukandana, and I.G.N.P. Tenaya, "Design and Testing of Oil Distillation Equipment from Plastic Waste,” vol. 6, no. 4, pp. 311-317, 2017.

[3] J. Wahyudi, H.T. Prayitno, and A.D. Astuti, "Pemanfaatan Limbah Plastik Sebagai Bahan Baku Pembuatan Bahan Bakar Alternatif," J. Litbang Media Inf. Penelitian, Pengemb. dan IPTEK, vol. 14, no. 1, pp. 58-67, 2018.
[4] G.L. Sari, "Kajian Potensi Pemanfaatan Sampah Plastik Menjadi Bahan Bakar Cair,' J. Tek. Lingkungan, Univ. Singaperbangsa Karawang, Karawang, 2017.

[5] Q. Rachmawati, "Pengolahan Sampah Secara Pirolisis Dengan Variasi Rasio Komposisi Sampah Dan Jenis Plastik.” Institut Teknologi Sepuluh Nopember, 2015.

[6] N.A. Abdullah, R. Novitaningrum, I.I. Hakim, N. Putra, and R.A. Koestoer, "Investigasi Proses Pirolisis Pada Non-Sweep Gas Fixed-Bed Reactor Untuk Memproduksi Asap Cair Dengan Bahan Baku BioMassa,”J. Rekayasa Mesin, vol. 18, no. 1, pp. 9-18, 2018.

[7] G.D.B. Sitepu, "Uji Berbagai Jenis Limbah Plastik Pada Metode Pirolisis," 2018.

[8] I. Ahmad, M.I. Khan., H. Khan., M. Ishaq., R. Tariq., K. Gul., and W. Ahmad, "Pyrolysis Study of Polypropylene and Polyethylene in to Premium Oil Products," pp. 1-38, 2014.

[9] F. Sembiring, C.W. Purnomo, and S. Purwono, "Catalytic Pyrolysis of Waste Plastic Mixture," in IOP Conference Series: Materials Science and Engineering, 2018, vol. 316, no. 1, p. 12020.

[10] S. Selamet and T. Hidayat, "Experimental Study of Biomass Selection to Produce Liquid Smoke Gases as a Preservative," vol. 6, no. 1, 2016.

[11] M. Sarwendah, F. Feriadi, T. Wahyuni, and T.N. Arisanti, "Pemanfaatan Limbah Komoditas Perkebunan Untuk Pembuatan Asap Cair/Utilization of Plantation Commodities Waste for Liquid Smoke," J. Penelit. Tanam. Ind., vol. 25, no. 1, pp. 22-30, 2019.

[12] S. Komarayati and L. Efiyanti, "Characteristics and Potential Utilization of Liquid Smoke Made from Trema, Nani, Merbau, Matoa and Malas Woods.," J. Penelit. Has. Hutan, vol. 36, no. 3, pp. 219-238, 2018. 